\title{
Student-Centered Teaching Approach Combined with Coaching and Mentoring Elements in Arabic Language Speaking Proficiency
}

\author{
Masyitoh Yaacob, Kaseh Abu Bakar \\ Faculty of Islamic Studies, National University of Malaysia, Bangi, Malaysia \\ Email: p88590@siswa.ukm.edu.my
}

How to cite this paper: Yaacob, M. and Bakar, K.A. (2018) Student-Centered Teaching Approach Combined with Coaching and Mentoring Elements in Arabic Language Speaking Proficiency. Open Access Library Journal, 5: e4684.

https://doi.org/10.4236/oalib.1104684

Received: May 28, 2018

Accepted: June 23, 2018

Published: June 26, 2018

Copyright $\odot 2018$ by authors and Open Access Library Inc.

This work is licensed under the Creative Commons Attribution International License (CC BY 4.0).

http://creativecommons.org/licenses/by/4.0/

\begin{abstract}
The acquisition of Arabic speaking skills becomes an important issue in Arabic language learning. So, the National University of Malaysia (UKM) has offered the PPPJ3503 Oral Arabic Language Course as one of the department's elective subjects to undergraduate degree students. The purpose of this study is to evaluate the proficiency of speaking in Arabic and identify improved language-speaking factor among students. This research was a quantitative case study using data from survey instruments and focus group interview. The focus group consisted of 21 study pants. The study questions focus on their speaking competence after attending Oral Arabic Language courses with a student-centered teaching approach combined with coaching and mentoring elements. The findings show that there are self-improvements in Arabic speaking proficiency among students taking the course. The improvements in Arabic speaking proficiency among students were caused by spontaneous activities, video recording assignments, Arabic Linguaphone textbooks, Arabic speaking drill exercises repeatedly, discussions in the lecture room and student's self-esteem. This Oral Arabic course has proven that student-centered teaching approach combined with coaching and mentoring elements is good to be applied in the teaching of spoken Arabic and Arabic in general. This study also identifies ways to improve Arabic speaking proficiency through a student-centered teaching approach combined with coaching and mentoring elements in teaching Arabic speaking skills.
\end{abstract}

\section{Subject Areas}

Education

\section{Keywords}

Teaching Arabic Language, Speaking Proficiency, Language Acquisition, 


\section{Introduction}

Spoken competence means high ability in speaking or communicating verbally [1]. Individuals who can speak are individuals who have the high level of communication skills. In the study by [2], proficiency means the ability to do things quickly and perfectly. Speaking is using a language to talk. In the context of this study, speaking efficiencies are meant to speak Arabic proficiency. This study was conducted on students who took the PPPJ3503 Oral Arabic Language course at the Arab Studies Department and Islamic Civilization, Faculty of Islamic Studies, The National University of Malaysia (UKM).

Speaking skills in Arabic learning are essential to ensure good language control [3]. To be proficient in speaking skills, students also need to be proficient in listening skills. When a student mastered the listening skills, and spoke a language well, he had mastered the language he learned. However, in order to achieve the second level of speaking skills, the language-speaking exercises need to be done continuously [2]. Theories alone are not enough if they are not practically followed. Therefore, students need to equip themselves with the theory of the language and then practice it with friends or speakers of the language learned.

To improve students' speaking Arabic proficiency, student-centered teaching approach combined with coaching and mentoring elements is applied in the PPPJ3503 Oral Arabic Language course. These coaching and mentoring elements have been widely used in various fields to enhance the skills, professionalism, individual self-development or organization. Among the areas of knowledge that often uses coaching and mentoring elements are education development [4], teacher professional development [5] [6] [7], staff development [8], management [9], school leadership [10], science field [11] and business management [12]. However, the coaching element is still used dominantly in sports and business [13]. Apart from these two areas, the field of education is also not left behind in the use of coaching and mentoring elements, especially in teaching and learning.

\section{Problem Statement}

Recent studies show that Arab-language students in IPTA are still weak in the mastery of Arabic-speaking skills. This disadvantage may be due to a weak level of Arabic language use. This is supported by the study by [14] indicating that $70 \%$ of students still cannot master Arabic speaking skills well even though they will become Arabic teachers after graduation. Students' weakness in speaking skills due to lack of vocabulary related topics and fear of Arabic grammar errors when speaking [15]. In addition, the learning environment in Malaysia does not 
have an environment that supports foreign language learning [16]. However, so far there has been a lack of research finding solutions to problems in Arabic speaking incompetence. Therefore, a study should be conducted to measure the proficiency of Arabic language instruction after learning through a semester in the PPPJ3503 Oral Arabic Language course using a student-centered teaching approach combine with coaching and mentoring elements.

\section{Objective of the Study}

The objectives of the study are as follows:

1) Evaluate the proficiency of speaking in Arabic among students;

2) Identify ways to improve the proficiency of speaking in Arabic among students.

\section{Importance of the Study}

This study is important and useful for Oral Arabic instructors to find solutions to problems of incompetence of students while speaking in Arabic. Among other contributions of this study is to strengthen the use of Arabic language among Malay students who take the Arabic language. In addition, this study is expected to be the basis of further study especially in the field of Arabic language teaching as a second language.

\section{Methodology}

This study uses quantitative approach with case study design. The data collection used is questionnaires instrument and focus group interview protocols. Questionnaires were answered by 21 study participants and a focus group interview session was held with all the research's participants. Data obtained were analyzed descriptively using ATLAS.ti version 8.0 software. For interpreting descriptive data, the research data is divided into two parts based on the objectives of the study. Response of the participants of the study and the results of the document analysis was set out to see the validity and reliability of the data obtained. All research findings will be discussed in depth as qualitative data are the main data for this study. The diversity of data sources also makes the study more interesting to be studied.

The research's participants were taken from the undergraduate students of the Department of Arabic Studies and Islamic Civilization, the Faculty of Islamic Studies, The International University of Malaysia (UKM) who took the course of Oral Arabic Language and the code of the subject is PPPJ3503. Table 1 shows the information of research's participants.

\section{Findings}

\subsection{The Student's Arabic Speaking Proficiency}

The student's Arabic speaking proficiency can be identified through a focus group interview regarding how this student-centered teaching approach combined 
Table 1. Information of Study Participants.

\begin{tabular}{|c|c|c|c|}
\hline $\begin{array}{c}\text { Study } \\
\text { Participants }\end{array}$ & Age & Faculty & Course \\
\hline P1 & 23 & Faculty of Islamic Studies & $\begin{array}{c}\text { Arabic Study and Islamic } \\
\text { Civilization }\end{array}$ \\
\hline $\mathrm{P} 2$ & 22 & Faculty of Islamic Studies & $\begin{array}{c}\text { Arabic Study and Islamic } \\
\text { Civilization }\end{array}$ \\
\hline P3 & 23 & Faculty of Islamic Studies & $\begin{array}{c}\text { Arabic Study and Islamic } \\
\text { Civilization }\end{array}$ \\
\hline $\mathrm{P} 4$ & 23 & Faculty of Islamic Studies & $\begin{array}{l}\text { Arabic Study and Islamic } \\
\text { Civilization }\end{array}$ \\
\hline P5 & 23 & Faculty of Islamic Studies & $\begin{array}{c}\text { Arabic Study and Islamic } \\
\text { Civilization }\end{array}$ \\
\hline P6 & 22 & Faculty of Islamic Studies & $\begin{array}{c}\text { Arabic Study and Islamic } \\
\text { Civilization }\end{array}$ \\
\hline P7 & 22 & Faculty of Islamic Studies & $\begin{array}{c}\text { Arabic Study and Islamic } \\
\text { Civilization }\end{array}$ \\
\hline P8 & 26 & Faculty of Islamic Studies & $\begin{array}{c}\text { Arabic Study and Islamic } \\
\text { Civilization }\end{array}$ \\
\hline P9 & 22 & Faculty of Islamic Studies & $\begin{array}{c}\text { Arabic Study and Islamic } \\
\text { Civilization }\end{array}$ \\
\hline P10 & 23 & Faculty of Islamic Studies & $\begin{array}{c}\text { Arabic Study and Islamic } \\
\text { Civilization }\end{array}$ \\
\hline P11 & 21 & Faculty of Islamic Studies & $\begin{array}{c}\text { Arabic Study and Islamic } \\
\text { Civilization }\end{array}$ \\
\hline P12 & 23 & Faculty of Islamic Studies & $\begin{array}{c}\text { Arabic Study and Islamic } \\
\text { Civilization }\end{array}$ \\
\hline P13 & 23 & Faculty of Islamic Studies & $\begin{array}{c}\text { Arabic Study and Islamic } \\
\text { Civilization }\end{array}$ \\
\hline P14 & 22 & Faculty of Islamic Studies & $\begin{array}{c}\text { Arabic Study and Islamic } \\
\text { Civilization }\end{array}$ \\
\hline P15 & 22 & Faculty of Islamic Studies & $\begin{array}{c}\text { Arabic Study and Islamic } \\
\text { Civilization }\end{array}$ \\
\hline P16 & 23 & Faculty of Islamic Studies & $\begin{array}{c}\text { Arabic Study and Islamic } \\
\text { Civilization }\end{array}$ \\
\hline P17 & 23 & Faculty of Islamic Studies & $\begin{array}{c}\text { Arabic Study and Islamic } \\
\text { Civilization }\end{array}$ \\
\hline P18 & 22 & Faculty of Islamic Studies & $\begin{array}{c}\text { Arabic Study and Islamic } \\
\text { Civilization }\end{array}$ \\
\hline P19 & 22 & Faculty of Islamic Studies & $\begin{array}{c}\text { Arabic Study and Islamic } \\
\text { Civilization }\end{array}$ \\
\hline P20 & 22 & Faculty of Islamic Studies & $\begin{array}{c}\text { Arabic Study and Islamic } \\
\text { Civilization }\end{array}$ \\
\hline $\mathrm{P} 21$ & 22 & Faculty of Islamic Studies & $\begin{array}{c}\text { Arabic Study and Islamic } \\
\text { Civilization }\end{array}$ \\
\hline
\end{tabular}


with coaching and mentoring elements helps improve the proficiency of the student's Arabic speaking. Based on the student's response, the level of student-speaking competency varies between individuals. Yet there is still an equality between them that $100 \%$ of students have experienced increased speaking efficacy after completing the courses taken more than $10 \%$.

Instruments used to measure Arabic speaking ability of students are questionnaires. The questionnaire relates to estimating of self-improvement in Arabic speaking proficiency after taking PPPJ3503 Oral Arabic Language courses distributed to students during the final evaluation of the semester. Overall, the estimate of student self-improvement for student's proficiency speaks Arabic item can be illustrated in the following table.

Table 2 shows the estimates of self-improvement of study participants in Arabic speaking proficiency. All research's participants have experienced an increase in Arabic speaking proficiency. There were 2 participants (9.52\%) who achieved a very high level of improvement. A total of 12 participants (61.90\%) had reached a high level and 5 participants (23.80\%) reached a moderate level. Only a participant (4.76\%) reached a low level in enhancing Arabic speaking proficiency. Based on this finding, the study participants have estimated that their Arabic speaking proficiency has increased after taking this course. This student's acknowledgment suggests that the teaching approach used throughout the course can improve the Arabic speaking proficiency of the students taking the course.

\subsection{Ways to Improve the Proficiency of Speaking in Arabic among Students}

The question of how a student-centered teaching approach and the coaching and mentoring elements used in the course helped to improve student's Arabic-speaking efficacy were answered through the focus group interview protocol used. The question is how does this course help you to improve your Arabic speaking proficiency? Based on the focus group interview, the student's responses point to the way the course improves the proficiency of speaking in Arabic. The improvements in Arabic speaking proficiency among students were caused by spontaneous speech (PK06 \& PK02).

(PK06:Dok/PK06(12/6/17)) "The activity or practice that has been done in lecture helps me to improve Arabic proficiency such as speaking in Arabic spontaneously. Likewise, with activities done outside of college. The spontaneous activities carried out greatly helped me to speak in Arabic."

Table 2. Self Improvement Estimation.

\begin{tabular}{ccccc}
\hline Self-Improvement Estimation & $\begin{array}{c}\text { Low } \\
0 \%-29 \%\end{array}$ & $\begin{array}{c}\text { Intermediate } \\
30 \%-59 \%\end{array}$ & $\begin{array}{c}\text { High } \\
60 \%-89 \%\end{array}$ & $\begin{array}{c}\text { Very High } \\
90 \%-100 \%\end{array}$ \\
\hline My proficiency speaks Arabic & $\begin{array}{c}1 \\
(4.76 \%)\end{array}$ & $\begin{array}{c}5 \\
(23.80 \%)\end{array}$ & $\begin{array}{c}13 \\
(61.90 \%)\end{array}$ & \begin{tabular}{c}
$(9.52 \%)$ \\
\hline
\end{tabular}
\end{tabular}


(PK02:Dok/PK02(12/6/17)) "The activities carried out primarily "spontaneous" concepts indirectly make the thinking mind in Arabic faster."

The use of Arabic Linguaphone textbook (PK08, PK19, PK06, PK03, PK04 \& PK20):

(PK08:Dok/PK08(12/6/17)) "By training with a conversation partner for the "Linguaphone" book regularly."

(PK19:Dok/PK19(12/6/17)) "Class activities like conversation exercises using Linguaphone books."

(PK06:Dok/PK06(12/6/17)) "In addition to Arabic books devoted to this course, activities or practices that have been conducted in lectures help me improve Arabic proficiency such as speaking in Arabic spontaneously."

(PK03:Dok/PK03(12/6/17)) "Referring to Arabic Linguaphone book."

(PK04:Dok/PK04(12/6/17)) "The situation in the various modules adds existing vocabulary in the self as well as the existing vocabulary."

(PK20:Dok/PK20(12/6/17)) "When given a module that helps add vocabulary."

Arabic speaking drill exercises repeatedly (PK13, PK07, PK14, PK01, PK12 \& PK11):

(PK13:Dok/PK13(12/6/17)) "Perform drills alone or in groups by speaking Arabic in front of the mirror."

(PK07:Dok/PK07(12/6/17)) "Perform drills alone or in groups by speaking Arabic in front of the mirror."

(PK14:Dok/PK14(12/6/17)) "By means of a wide variety of communication exercises conducted both in and out of the classroom on a continuous and applied theoretical and practical basis."

(PK01:Dok/PK01(12/6/17)) "The opportunities given in the classroom range from daily conversations to serious current issues."

(PK12:Dok/PK12(12/6/17)) "The process of continuous learning and communication has trained the students' competence in Arabic. Students are also given the time to prepare before speaking in front of the audience. In addition, there is a further stage that requires students to perform and communicate without any effort. This situation indirectly honed and trained Arabic language communication."

(PK11:Dok/PK11(12/6/17)) "Through diverse activities in the classroom. Among them is the practice of calling the phone number and time in Arabic. This repetition process helps me to efficiently answer questions promptly and correctly."

Discussions in the lecture room (PK15 \& PK21):

(PK15:Dok/PK15(12/6/17)) "Discussions conducted in coaching and mentoring classes in various issues. Starting from common titles such as daily conversations to touching on key issues that take place in the globalization issue."

(PK21:Dok/PK21(12/6/17)) "It starts from the ground up through the next brainstorm to important issues."

Video recording assignments (PK16, PK18 \& PK10): 
(PK16:Dok/PK16(12/6/17)) "This course is both theoretical and practical. Always train yourself to speak Arabic. There are tasks that can help in speaking. Like the videos."

(PK18:Dok/PK18(12/6/17)) "Class-based activities that cover multiple levels of speech are helpful in this regard especially with daily conversations and video projects."

(PK10:Dok/PK10(12/6/17)) "With the activities in the classroom helps us speak Arabic. Additionally, through the assignment videos that need to be provided."

And student's self-esteem (PK05 \& PK09):

(PK05:Dok/PK05(12/6/17)) "I challenge myself and put faith in myself to continue to answer the question of making a long preparatory. As a result, word-by-word Arabic words appear one by one even stuttering while speaking."

(PK09:Dok/PK09(12/6/17)) "Self-confidence has been gained throughout the course. This indirectly made me more determined to continue communicating in Arabic."

\section{Discussion}

\subsection{The Student's Arabic Speaking Proficiency}

From the above findings, there is a link between Arabic speaking proficiency and the ways to improve Arabic speaking proficiency. This study found that Arabic speaking proficiency among PPPJ3505 Oral Arabic Language course in UKM has increased based on their response in questionnaires instruments. The result shows that only a participant $(4.76 \%)$ reached a low level (0\% to $29 \%)$ in enhancing Arabic speaking proficiency while the other participants $(95.24 \%)$ had reached $30 \%$ to $100 \%$ in their self-improvement estimation either intermediate, high and very high level. This student achievement in their self-improvement estimation in Arabic speaking proficiency shows that there are some factors that help in this improvement. These factors have been identified from the focus group interview with the participants. Focus group interviews have revealed how the participants Arabic speaking proficiency can increase as shown in Table 2.

\subsection{Spontaneous Speech}

The increase in study participants Arabic speaking proficiency occurs when they are given a topic closer to themselves when doing the spontaneous speech. During the activity, the students acknowledge that they can detect their own weaknesses during the activity. Spontaneous speech is usually associated with the students' daily lives until current issues occur in the Arab world. However, when they are given a higher level of difficult topics such as Arab countries' global issues, their speaking proficiency becomes diminished due to the lack of information and the related words. This situation coincides with previous studies which found that among the factors the students were unable to speak well was due to lack of vocabulary related to a particular topic [14] [17] [18] [19]. 


\subsection{The Use of Arabic Linguaphone Textbook}

Among the solutions to the lack of vocabulary among students is with the use of Arabic Linguaphone textbook. The book can help the student to add their vocabulary, phrases and sentences structure that students can speak. They are required to memorize the contents of the book to overcome the problem of vocabulary shortage. When the problem of lack of vocabulary has been overcome, then the student becomes more efficient to speak. Apart from the use of Arabic Linguaphone textbook, Arabic speaking drill exercises repeatedly also help the student to increase their Arabic speaking proficiency.

\subsection{Arabic Speaking Drill Exercises Repeatedly}

Arabic speaking drill exercises repeatedly are related with spontaneous speech activities. The student must do their spontaneous speech repeatedly to make sure their language error is getting reduced and students are smoother while speaking the Arabic language about any topic after this. The finding of this study differs slightly with [20] study found that there was an influence of the pattern drill learning method to improve the Arabic language proficiency of students at SMPI al-Fatahiyyah Boyolongu Tulungagung. When the student performs the activity, the lecturer plays a role in guiding students and correcting the language mistakes students do from time to time. During the coaching and mentoring and language mistakes correction session, there was no negative feedback given by lecturers and even lecturer was more celebrating the wishes of students.

\subsection{Discussions in the Lecture Room}

Other things that can help students to speak effectively are discussions in lecture room. The discussion in the lecture room include discussions about problems faced by students when they want to speak Arabic, discussions on issues of Arabic speaking anxiety, issues of willingness to communicate in Arabic language and speech strategies that students can use. Through these discussions, students can identify the problems they face during the time when they want to speak Arabic. After learning about the problems, the discussion also includes ways to overcome these problems, among others, with the use of a speech-based word that is suited to each student. So that, student's proficiency of speaking Arabic improved to a better stage.

\subsection{The Videos Recording Assignments}

Most of the videos recording assignments provided require students to do so outside the lecture room individually or in groups. The video recording titles that students need to do is Al-hiwar Fi Al-mat'am Arabiya, singing the national anthem of the Arab countries, Arabic cuisine, introducing Malaysia mosque and intercultural exchange. The focus group interview with students found that most students liked the video recording assignment because the assignment forced them to speak Arabic. The recording of these videos is also capable of enhancing their speaking Arabic proficiency. This finding was in line with [21] study that 
learning Arabic speaking skills is more effective and efficient with the use of contemporary learning media.

\subsection{Student Self-Esteem}

Lastly, self-esteem should be in each student. Without self-esteem, students will never speak Arabic, so that students will not be able to improve their Arabic speaking proficiency. Self-esteem comes from within and encouragement from their friends and lecturer. Therefore, attempts to increase the self-esteem in each student must be done by convincing them that they are able to do so without expecting other people's help. In that way, students will work to improve their Arabic speaking proficiency by themselves.

\section{Implication of Study}

The implication of this study on teaching practice is the coaching and mentoring approach in the teaching of Oral Arabic language can influence the acquisition of Arabic among students. This is evidenced by research findings that tend to indicate that students' Arabic speaking proficiency had increased. Therefore, this student-centered teaching approach combine with coaching and mentoring elements has a positive effect on student's Arabic speaking proficiency.

In addition to the implications for improved Arabic-speaking proficiency, this study also provided practical implications to lecturers to implement identified activities that could contribute to improved student Arabic speaking competence. The identified activities that could contribute to improving student Arabic speaking competence are spontaneous speech, Arabic speaking drill exercises repeatedly, discussions in lecture room about various issues and the recording videos assignments.

\section{Conclusion}

Overall, this study found that the level of proficiency of speaking the students following the course has increased based on the findings. The increase in Arabic speaking proficiency results from a student-centered teaching approach combined with coaching and mentoring elements used by the lecturer. Lecturer also plays an important role in improving their speaking proficiency, as coach and mentor to students. The lecturer is individual who is responsible for providing teaching material, planning teaching activities and assigning appropriate tasks to improve student's Arabic speaking proficiency. Student's self-esteem has also increased when they have close relationships with lecturers and at the same time lecturers are considered an idol and source of inspiration to them. The student's Arabic speaking proficiency has also improved after being guided and trained by the lecturer. Therefore, this teaching approach can help students improve their Arabic speaking proficiency.

\section{References}

[1] Ahmad, Z. (2009) Keterampilan bertutur dalam kalangan pelajar Institut Pendidi- 
kan Guru di Selangor. Universiti Putra Malaysia.

[2] Baharudin, M. (2014) Pemerolehan dan penguasaan kecekapan berbahasa Melayu dalam kalangan pelajar asing di Universiti Sains Malaysia. Procedia-Social and Behavioral Sciences, 134, 270-275. https://doi.org/10.1016/j.sbspro.2014.04.248

[3] Muhammad, A., Jasmi, K.A., Mustari, M.I., Sackkani, S. and Ali, F. (2012) Kemahiran bertutur dalam pengajaran dan pembelajaran bahasa Arab. Seminar Antarabangsa Perguruan dan Pendidikan Islam [SEAPPI2012], hlm. 889-899.

https://www.researchgate.net/publication/293097748_Kemahiran_Bertutur_dalam_ Pengajaran_dan_Pembelajaran_Bahasa_Arab

[4] McCann, S. and Delap, J. (2015) Mentoring Case Studies in the Access and Civic Engagement Office, Dublin Institute of Technology. International Journal of Evidence Based Coaching and Mentoring, 13, 106-120.

http://ijebcm.brookes.ac.uk/

[5] Pleschová, G. and McAlpine, L. (2015) Enhancing University Teaching and Learning through Mentoring. International Journal of Mentoring and Coaching in Education, 4, 107-125. https://doi.org/10.1108/IJMCE-06-2014-0020

[6] Zepeda, S.J., Parylo, O. and Ilgan, A. (2013) Teacher Peer Coaching in American and Turkish Schools. International Journal of Mentoring and Coaching in Education, 2, 64-82. https://doi.org/10.1108/20466851311323096

[7] Zhang, S., Liu, Q. and Wang, Q. (2016) A Study of Peer Coaching in Teachers' Online Professional Learning Communities. Universal Access in the Information Society, 1-11.

[8] Harding, C. (2013) The Transitional Space Provided by Coaching and Mentoring. International Journal of Evidence Based Coaching and Mentoring, No. 7, 56-72.

[9] Filsinger, C. (2014) The Virtual Line Manager as Coach: Coaching Direct Reports remotely and Across Cultures. International Journal of Evidence Based Coaching and Mentoring, 12, 188-202.

http://ijebcm.brookes.ac.uk/documents/vol12issue2-paper-13.pdf

[10] Rhodes, C. and Fletcher, S. (2013) Coaching and Mentoring for Self-Efficacious Leadership in Schools. International Journal of Mentoring and Coaching in Education, 2, 47-63. https://doi.org/10.1108/20466851311323087

[11] Lunsford, L.G. (2014) International Journal of Mentoring and Coaching in Education. International Journal of Mentoring and Coaching in Education ISS Library Review Journal of Documentation ISS Journal of Economic Studies, 3, 4-17.

[12] Darwin, A. (2015) Graduates Giving Back-A Mentoring Program for MBA Students. International Journal of Mentoring and Coaching in Education.

[13] Garvey, B., Stokes, P. and Mengginson, D. (2014) Coaching and Mentoring, Hlm. 2nd Edition, SAGE, Los Angeles.

[14] Daud, N. and Pisal, N.A. (2014) Permasalahan pertuturan dalam bahasa Arab sebagai bahasa kedua. GEMA Online Journal of Language Studies, 14, 117-133. http://journalarticle.ukm.my/7003/

[15] Ali, A.M. and Manaf, M.F.H.A. (2014) Kekangan bertutur dalam bahasa Arab di kalangan pelajar BASL. International Research Management and Innovation Conference 2014 (IRMIC2014), Hlm, 584-599.

[16] Klein, W. (1986) Second Language Acquisition. Cambridge Textbooks in Linguistics.

[17] Sopian, A. (2016) Tahap pertuturan bahasa Arab dalam kalangan pelajar yang mengambil Kursus Bahasa Arab Di UITM Melaka. International Conference on 
Arabic Studies and Islamic Civilization, 3 March 2016, 14-15.

[18] Hashim, M.H.M., Ismail, M.Z. and Mustafa, N.F. (2014) "Alamak! Macamana nak cakap ni?”: Penggunaan strategi tampungan dalam komunikasi lisan bahasa Arab. Global Media Journal-Malaysian Edition, 4, 152-168.

http://psasir.upm.edu.my/36353/1/Alamak.pdf

[19] Ismail, M.Z., Bakar, K.A., Mustapha, N.F.N. and Rouyan, N.M. (2016) Strategi pembelajaran kosa kata berimbuhan bahasa Arab. Malaysian Journal of Learning and Instruction, 13, 113-133. http://mjli.uum.edu.my

[20] Maslaha, A. (2016) Pengaruh metode pattern drill untuk meningkatkan maharah kalam di Sekolah Menengah Pertama Islam Al-Fatahiyyah Boyolangu Tulungagung tahun ajaran 2015/2016. Institut Agama Islam Negeri Tulungagung.

[21] Hasanuddin, H. (2016) Istikhdam wasail al-taalim al-hadithah litarqiyah maharat al-kalam (bitatbiq ala al-tullab qismi al-lughah bi al-Madrasah al-Thanawiyah al-Islamiyyah al-Hukumiyyah al-Thani Tulungagung li al-am al-dirasi 2015/2016 Masihi). al-Jamiah al-Islamiyyah al-Hukumiyyah Tulungagung. 